\title{
Potensi Paparan Pestisida Dan Dampak Pada Kesehatan Reproduksi Wanita Tani Studi Di Kabupaten Brebes
}

\author{
Sigit Ambar Widyawati ${ }^{1}$, Yuliaji Siswanto ${ }^{2}$, Puji Pranowowati ${ }^{3}$ \\ 1,2,3 Universitas Ngudi Waluyo \\ email : sigitambar@gmail.com
}

\begin{abstract}
Abstrak
Penggunaan pestisida dewasa ini semakin intensif untuk meningkatkan hasil pertanian. Selain bermanfaat, pestisida juga memiliki potensi yang membahayakan. Pada tahun 2008 pestisida dilaporkan menjadi bahan ke sembilan yang paling banyak menyebabkan keracunan. Pengguna pestisida bukan hanya petani pria, tetapi juga oleh wanita tani sehingga berpotensi mengganggu kesehatan reproduksinya. Penelitian ini bertujuan mengidentifikasi potensi paparan pestisida dan dampak pada kesehatan reproduksi wanita tani. Metode penelitian yang digunakan adalah metode deskriptif dengan lokasi penelitian dipilih secara purposive sampling di Kabupaten Brebes, yakni pada lokasi penanaman bawang merah yang intensif penggunaan pestisidanya. Hasil penelitian menunjukkan: 1) para wanita tani juga terlibat dalam berbagai kegitan pertanian, 2) ada potensi penggunaan pestisida yang cukup tinggi dengan dosis diatas dosis yang dianjurkan, 3) ada hubungan antara lama pajanan pestisida dengan kesehatan reproduksi wanita tani, berupa kejadian berat bayi lahir ringan BBLR dan abortus, 4) analisis metabolit DAP dari sampel urin 5 wanita tani menunjukkan 1 orang $(20 \%)$ terbukti mengalami paparan pestisida. Disarankan penggunaan pestisida secara selektif, hati-hati dan sesuai dosis yang dianjurkan, dengan menggunkan alat pelindung diri (APD) yang lebih baik, sehingga tidak berdampak pada kesehatan reproduksi wanita tani.
\end{abstract}

Kata kunci: paparan pestisida, kesehatan reproduksi

\section{Pendahuluan}

Pestisida telah digunakan secara luas untuk meningkatkan hasil-hasil produksi pertanian, perkebunan, dan memberantas vektor penyakit (Priyanto, 2009). Pada tahun 2008 pestisida dilaporkan merupakan substansi ke sembilan yang paling banyak menyebabkan keracunan (Robert et al., 2012). Dari penelitian Sathayanarayana et al. (2010) lebih dari 700 juta pon pestisida digunakan setiap tahun di bidang pertanian di Amerika Serikat dimana dari data penelitian dijumpai peningkatan paparan pestisida pada kelompok petani dan keluarga yang tinggal di daerah sekitar pertanian dibandingkan dengan kelompok yang bukan petani dan tidak tinggal disekitar daerah sekitar pertanian. Selain
Amerika Serikat, penelitian lain juga memperlihatkan bahwa penggunaan pestisida di beberapa negara cukup tinggi misalnya penelitian yang dilakukan Liang et al. (2012), Brazil mencapai 113.993 ton pada tahun 1997 dan Cina melebihi 300.000 ton pestisida setiap tahunnya.

Setiap hari ribuan petani dan para pekerja di sektor pertanian teracuni oleh pestisida dan setiap tahun diperkirakan jutaan orang yang terlibat di pertanian menderita keracunan akibat pestisida. Dalam beberapa kasus keracunan pestisida, petani dan para pekerja pertanian lainnya terpapar pestisida pada proses mencampur dan menyemprotkan pestisida. Selain itu masyarakat sekitar lokasi 
pertanian sangat beresiko terpapar pestisida (Kusumawati, 2010).

Kaum wanita yang terlibat dalam aktivitas tersebut pada umumnya turut membantu suami bertani dan juga menjadi buruh tani untuk lahan orang lain. Kegiatan tersebut memungkinkan mereka untuk terpajan pestisida. Di Indonesia, menurut data pertanian tahun 2008 menyatakan 50,28\% dari total jumlah tenaga kerja sektor pertanian adalah perempuan (FAO, 1990).

Besarnya paparan pestisida pada wanita petani tergantung dari pekerjaan, lama paparan, frekuensi paparan, penyimpanan pestisida, pencampuran pestisida dan penanganan peralatan pestisida serta penggunaan alat pelindung diri. Risiko pajanan pestisida yang diperoleh wanita petani diantaranya adalah saat ibu hamil ikut bekerja mencari hama, mencabut rumput tanaman, menyiram tanaman, memanen, melepaskan bawang dari tangkainya, memupuk, menyiapkan pestisida semprot, mencuci pakaian yang dipakai untuk menyemprot, keberadaan tanaman bawang dan pestisida dalam rumah. Aktivitas tersebut memungkinkan pestisida masuk ke dalam tubuh melalui mulut/ oral (ingesti), kulit (absorpsi), pernafasan (inhalasi), serta melalui mekanisme rantai makanan (Hoang, 2010).

Pestisida golongan sintetik yatg banyak digunakan petani di lndonesia adalah golongan organofosfat yang dapat masuk ke dalam tubuh melalui alat pencernaan atau digesti, saluran pernafasan atau inhalasi dan melalui permukaan kulit yang tidak terlindungi atau penetrasi. Pestisida organofosfat dapat mempengaruhi fungsi syaraf dengan jalan menghambat kerja enzim kholinesterase, suatu bahan kimia esensial dalam menghantarkan impuls sepanjang serabut syaraf (Achmadi, 2005).

Lokasi penelitian dilakukan di Kabupaten Brebes, yang merupakan salah satu daerah di Jawa Tengah dengan tingkat pemakaian pestisida yang cukup tinggi, karena luasnya lahan pertanian, khususnya bawang merah yang membutuhkan perawatan dengan pestisida dalam jumlah yang sangat tinggi. Berdasar data yang diperoleh dari data Dinas Pertanian, Tanaman Pangan, dan Hortikultura Brebes, sentra bawang merah tersebar di Kecamatan Brebes adalah di Kecamatan Wanasari, Bulakamba, Losari, Tanjung, Kersana, Ketanggungan, Larangan, Songgom, Jatibarang, Bantarkawung dan sebagian Banjarharjo.

Hasil wawancara dengan beberapa wanita tani di Kabupaten Brebes, menunjukkan bahwa tingkat penggunaan pestisida di daerah tersebut sangat tinggi dan intensif. Pada umumnya para petani melakukan campuran sekitar 3 jenis pestisida dengan frekuensi menyemprot hampir setiap hari agar terhindar dari hama tanaman bawang. Desa Sigentong, merupakan salah satu desa di Kecamatan Sidamulya, Kabupaten Brebes dengan tingkat pemakaian pestisida yang tergolong tinggi. Berkaitan dengan hal tersebut, perlu dilakukan kajian tentang potensi paparan pestisida wanita tani dan dampak pada kesehatan reproduksi wanita tani.

\section{Metode Penelitian}

Penelitian ini adalah penelitian deskriptif menggunakan desain penelitian cross sectional dengan populasi target adalah semua wanita tani yang bertempat tinggal di daerah pertanian bawang merah. Sdangkan populasi terjangkau adalah wanita tani yang bertempat tinggal di Desa Sigentong, Kecamatan Sidamulya, Kabupaten Brebes. Desa tersebut dipilih secara purposif, dengan pertimbangan bahwa sebagai produsen bawang merah dengan tingkat pemakaian pestisida di desa tersebut tergolong tinggi. Subjek penelitian adalah sebanyak 43 wanita yang bertempat tinggal di desa Sigentong. Kriteria inklusi subjek adalah tidak sedang hamil dan tidak sedang menderita sakit berat. 
Variabel yang diukur untuk seluruh subjek meliputi karakteristik subjek (umur, pekerjaan, status perkawinan, umur suami, pekerjaan suami), keterlibatan subyek dalam kegiatan pertanian (kebiasaan menggunakan pestisida, merk pestisida yang dipakai, kesesuaian dosis pestisida yang dipakai, jumlah penggunaan jenis pestisida, keterlibatan responden dalam kegiatan pertanian, lama responden terlibat dalam kegiatan pertanian) dan riwayat kesehatan reproduksi.

Untuk mendeteksi adanya paparan pestisida, dilakukan pemeriksaan urin. Untuk melihat perubahan kadar DAP yang disimpan selama 3 bulan, diambil urin dari 5 responden. Jumlah subjek yang diambil urinnya ditentukan berdasarkan judgement peneliti, dengan memperhitungkan ketersediaan biaya. Analisis statistik menggunakan SPSS 15.0 for windows.

Hasil Dan Pembahasan

1. Karakteristik Responden

Tabel 1. Karakteristik Responden

\begin{tabular}{|c|c|c|}
\hline Karakteristik & $\begin{array}{c}\text { Frekuensi } \\
(n=43)\end{array}$ & $\%$ \\
\hline \multicolumn{3}{|l|}{ Umur (th) } \\
\hline$\leq 20$ tahun & 4 & 9.4 \\
\hline 21-34 tahun & 20 & 53.7 \\
\hline$\geq 35$ tahun & 19 & 44.3 \\
\hline \multicolumn{3}{|l|}{ Pekerjaan } \\
\hline Petani & 41 & 95,3 \\
\hline IRT/Buruh Tani & 2 & 4,7 \\
\hline \multicolumn{3}{|l|}{ Status perkawinan } \\
\hline Menikah & 43 & 100.0 \\
\hline Tidak menikah & 0 & 0 \\
\hline \multicolumn{3}{|l|}{ Pekerjaan suami } \\
\hline Petani & 42 & 97.7 \\
\hline Buruh tani & 1 & 2.3 \\
\hline
\end{tabular}

Sumber: Data Primer

Terlihat bahwa hampir semua wanita tani juga melakukan/membantu kegiatan pertanian dan semua wanita tani dalam status menikah.

Keikutsertaan wanita tani dalam kegiatan pertanian menyebabkan mereka terpapar pestisida secara langsung. Dari hasil wawancara diperoleh informasi bahwa para wanita melakukan kegiatan seperti mencari hama, mencabut rumput tanaman, menyiram tanaman, memanen, melepaskan bawang dari tangkainya, dan mencuci pakaian suami yang dipakai sewaktu menyemprot. Aktivitas tersebut memungkinkan pestisida masuk ke dalam tubuh melalui mulut/oral (ingesti), kulit (absorpsi), pernafasan (inhalasi), serta melalui mekanisme rantai makanan ${ }^{16}$.

2. Kebiasaan menggunakan pestisida Tabel 2. Jenis dan Dosis Pestisida

\begin{tabular}{lrr}
\hline $\begin{array}{l}\text { Merk pestisida yang } \\
\text { dipakai }\end{array}$ & $\begin{array}{c}\text { Frekuensi } \\
(\mathbf{n = 4 3 )}\end{array}$ & \multicolumn{1}{c}{} \\
\hline$>1$ jenis & 39 & 90.7 \\
1 jenis & 4 & 9.3 \\
\multicolumn{1}{c}{ Jumlah } & $\mathbf{4 3}$ & $\mathbf{1 0 0 . 0}$ \\
\hline Sesuai & 10 & 23.3 \\
Diatas dosis anjuran & 33 & 76.7 \\
$\quad$ Jumlah & $\mathbf{4 3}$ & $\mathbf{1 0 0 , 0}$ \\
\hline
\end{tabular}

Sumber: Data Primer

Sebagian besar (90,7\%) menggunakan lebih dari satu jenis pestisida dan lebih dari dua pertiga $(76,7 \%)$ menggunakan dosis di atas dosis yang dianjurkan. Petani di Indonesia banyak yang mengetahui pestisida, namun mereka tidak peduli dengan akibat pestisida. Berdasarkan hasil penelitian yang pernah dilakukan untuk menguji tingkat kesehatan penduduk akibat paparan Organofosfat dan Karbamat di daerah sentra produksi padi, sayuran dan bawang merah menunjukkan bahwa aktivitas asetilkolinesterase yang kurang dari 4500 UI pada darah petani di Kabupaten Brebes sebanyak 32,53 \% petani, di Cianjur 43,75\% dan di Indramayu $40 \%$.

Petani sebagai kelompok pekerja yang sering terpapar pestisida kadang-kadang memiliki kebiasaan dalam penggunaan pestisida yang menyalahi aturan baik dalam hal penggunaan dosisy ang melebihi 
takaran ataupun mencampurkan beberapa jenis Pestisida (Achmadi, 2005; Wudianto, 2008).

\section{Lama terlibat dalam kegiatan pertanian}

Tabel 3. Lama terlibat dalam kegiatan pertanian

\begin{tabular}{lrr}
\hline $\begin{array}{c}\text { Lama ibu terlibat } \\
\text { dalam kegiatan } \\
\text { pertanian }\end{array}$ & $\begin{array}{c}\text { Frekuensi } \\
(\mathbf{n = 4 3 )}\end{array}$ & $\mathbf{\%}$ \\
\hline$<5$ Tahun & 11 & 25.7 \\
5 -10 Tahun & 13 & 30.3 \\
$\geq 11$ Tahun & 19 & 44.0 \\
Jumlah & 43 & 100,0 \\
\hline
\end{tabular}

Sumber: Data Primer

Para wanita tani telah terlibat dan membantu dalam kegiatan pertanian, termasuk menggunakan pestisida, dalam waktu yang lama. Temuan dalam penelitian ini menunjukkan bahwa 44,0\% wanita tani terpapar pestisida $\geq 11$ tahun. Semakin lama wanita tani terlibat dalam kegiatan pertanian maka kontak dengan pestisida pun akan semakin lama dan risiko keracunan pestisida pun semakin tinggi.

Lama kerja mengakibatkan berbedanya intensitas pajanan dan banyaknya pestisida yang terabsorbsi oleh masing-masing petani bawang, sehingga petani bawang yang cukup lama terlibat dalam aktivitas pertaniannya, berpotensi mengabsorbsi pestisida lebih banyak jika dibandingkan dengan petani bawang yang tidak lama terlibat dalam aktivitas pertaniannya. (Siwiendrayanti, 2010).

Masa kerja dalam kegiatan pertanian yang lama mernungkinkan istri mengalami lebih lama terpapar pestisida, sehingga berpotensi untuk terjadi bioakumulasi residu pestisida di dalam tubuhnya, yang pada akhimya akan terjadi penurunan kadar kolinesterase sehingga menyebabkan keracunan. Pada istri pemakai pestisida yang lama pemakaiannya berkisar 6-10 tahun, menunjukkan kadar kolinesterase darah yang tinggi berarti telah mengalami keracunan tingkat berat (Mukono, 1985).

\section{Riwayat kesehatan reproduksi}

Tabel 4. Riwayat Kesehatan Reproduksi

\begin{tabular}{|c|c|c|}
\hline $\begin{array}{l}\text { Riwayat kesehatan } \\
\text { reproduksi }\end{array}$ & $\begin{array}{c}\text { Frekuensi } \\
(n=43)\end{array}$ & $\%$ \\
\hline Tidak ada & 33 & 76.7 \\
\hline BBLR & 2 & 4.7 \\
\hline Abortus & 8 & 18.6 \\
\hline Jumlah & 43 & 100,0 \\
\hline
\end{tabular}

Sumber: Data Primer

Dari data riwayat kesehatan reproduksi, ternyata ada lebih dari $20 \%$ wanita tani yang mengalami masalah, berupa berat bayi lahir rendah (BBLR) $4,7 \%$ dan keguguran $18,6 \%$.

Salah satu faktor yang dapat mempengaruhi kondisi ibu selama hamil dan janin yang dikandungnya adalah faktor lingkungan, khususnya paparan pestisida. Penelitian di Cina membuktikan bahwa riwayat paparan pestisida golongan organofosfat pada ibu hamil merupakan faktor risiko kejadian gangguan tumbuhkembang pada neonates (Zhang, 2014).

Ketika wanita terpapar pestisida selama kehamilan, beberapa bahan kimia akan masuk secara langsung ke janin dalam kandungan. Selama masa perkembangannya, janin sangat rentan terhadap dampak racun dari pestisida (Allsop, 2015).

Pada penelitian penduduk perkebunan di Ontario, Kanada oleh Arbuckle et al 2001, terjadi peningkatan risiko abortus spontan pada kehamilan awal $(<12$ minggu) pada paparan phenoxy acetic acid herbisides dengan nilai $(\mathrm{OR})=1,5$, pada paparan triazines $(\mathrm{OR})=1,4$ dan pada beberapa herbisida $(\mathrm{OR})=1,4$. Sedangkan pada kehamilan (12-19 minggu) paparan glyposate $(\mathrm{OR})=1,7$, pada paparan thiocarbamates $(\mathrm{OR})=1,8$ dan pada 
paparan bermacam-macam pestisida (OR) $=1,5$ (Arbuckle, 2001).

\section{Hubungan antara lama paparan dengan riwayat kesehatan reproduksi}

Dari data lama pekerjaan menjadi petani, sebagai proksi lama paparan pestisida, dan riwayat kesehatan reproduksi menunjukkan data sebagai berikut:

Tabel 5 Hubungan Lama Paparan dengan Riwayat Kesehatan Reproduksi

\begin{tabular}{cccccc}
\hline \multirow{2}{*}{ Kategori } & \multicolumn{3}{c}{ Kasalah Kesehatan } \\
\cline { 3 - 5 } & & Tdk & & \\
& & Ada & BBLR & Abortus \\
\hline \multirow{2}{*}{ Jenis } & 1-Jenis & 29 & 2 & 8 & 39 \\
& 2-Jenis & 4 & 0 & 0 & 4 \\
\hline \multicolumn{2}{c}{ Total } & 33 & 2 & 8 & 43 \\
\hline \multirow{2}{*}{ Dosis } & Sesuasi & 8 & 0 & 2 & 10 \\
& Diatas & 25 & 2 & 6 & 33 \\
\hline \multicolumn{2}{c}{ Total } & 33 & 2 & 8 & 43 \\
\hline Lama & $<5$ & 10 & 0 & 0 & 10 \\
Terlibat & $5-10$ & 10 & 2 & 2 & 14 \\
(tahun) & $\geq 11$ & 13 & 0 & 6 & 19 \\
\hline \multicolumn{2}{c}{ Total } & 33 & 2 & 8 & 43 \\
\hline
\end{tabular}

Sumber: Data Primer

Terlihat bahwa ada hubungan antara penggunaan pestisida yang melebihi dosis anjuran dan lama paparan dengan kesehatan reproduksi. Hasil penelitian ini sesuai dengan penelitian yang menunjukkan adanya hubungan erat antara lama paparan pestisida terhadap kejadian BBLR didapatkan bahwa keterlibatan ibu hamil dalam kegiatan pertanian, keberadaan pestisida dalam rumah, kelengkapan alat pelindung diri, keberadaan hasil pertanian terhadap BBLR ditemukan berkaitan erat (Sari et al., 2013; Setiyobudi et al., 2013 ). Menurut Kim (2011) pestisida golongan organofosfat seperti klorpyrifos, diazinon, and malathion merupakan pestisida yang berpengaruh terhadap berat badan bayi lahir.
Pestisida dapat menyebabkan kerusakan yang paling dalam pada manusia selama periode perkembangan yang cepat terutama dalam rahim. Bahkan sebelum periode janin peningkatan sensitivitas, penelitian telah menemukan bahwa paparan prakonsepsi dari baik ibu atau ayah mungkin memiliki efek pada hasil reproduksi dan keturunannya (Abadi, 2006; Murphy, 2010).

Risiko abortus spontan telah diteliti pada sejumlah kelompok istri-istri pekerja. Wanita yang bekerja di pertanian mempunyai kemungkinan lebih besar untuk mengalami kejadian abortus spontan dibandingkan wanita yang tidak terpajan. Penelitian pada 209 pasangan hidup di Italia pada tahun 2000, yang bekerja di kebun rumah kaca, terjadi peningkatan risiko abortus spontan dikarenakan adanya pajanan pestisida dengan nilai $(\mathrm{OR})=11,8$ (Pretelli, 2003).

\section{Pemeriksaan kadar dialkil metabolit fosfat (DAP)}

Tabel 6. Hasil pemeriksaan kadar DAP

\begin{tabular}{lcc}
\hline Responden & $\begin{array}{c}\text { Kadar DAP } \\
\text { (Pemeriksaan } \\
\text { pertama) } \\
\text { ppm(mg/L) }\end{array}$ & $\begin{array}{c}\text { Kadar DAP } \\
\text { (Pemeriksaan } \\
\text { setelah } \\
\text { disimpan } \\
\text { selama 3 } \\
\text { bulan) }\end{array}$ \\
\hline R 1 & ND & ND \\
R 2 & 0,001 & ND \\
R 3 & 0,002 & ND \\
R4 & 0,006 & ND \\
R5 & 0,008 & ND \\
\hline ND2 tidak terdeteki
\end{tabular}

$\mathrm{ND}=$ tidak terdeteksi

Terlihat bahwa dari sampel urin 5 wanita tani dapat diidentifikasi keberadaan metabolit DAP pada 4 orang. Ini berarti ada $80 \%$ wanita tani yang terbukti terpapar pestisida. Akan tetapi, hasil pada pemeriksaan sampel urin kedua, setelah disimpan di Laboratorium selama 3 bulan, 
metabolit DAP tersebut tidak terdeteksi lagi.

Pemeriksaan metabolit pestisida
dalam urin merupakan metode
pemeriksaan yang cukup sensitif dan reliabel untuk menentukan adanya paparan pestisida pada seseorang (Egeghy, 2011). Meskipun DAP urin bermanfaat sebagai biomarker paparan pestisida organophospate, tetapi pemeriksaan ini memiliki keterbatasan bahwa organophospate memiliki waktu paruh yang pendek dalam tubuh. Dengan demikian pemeriksaan urin DAP hanya mewakili paparan jangka pendek dan bukan paparan yang terus-menerus (EPA, 2002)

\section{Kesimpulan Dan Saran}

Dari data-data yang diperoleh dapatlah disimpulkan bahwa:

1) Dalam statusnya sebagai isteri petani, para wanita tani juga terlibat dalam berbagai kegiatan pertanian yang cukup lama dan intensif, termasuk dalam penggunan petisida;

2) Penggunaan pestisida di Kab. Brebes menunjukkan potensi penggunaan yang cukup tinggi dengan dosis di atas dosis yang dianjurkan,

3) Secara deskriptif dapat disimpulkan adanya hubungan antara lama paparan pestisida dengan kesehatan reproduksi wanita tani, berupa kejadian berat bayi lahir ringan BBLR dan abortus.

4) Identifikasi metabolit DAP, menunjukkan ada 4 orang $(80 \%)$ yang terbukti mengalami paparan pestisida. Akan tetapi, kadar metabolit DAP sesudah disimpan selama 3 bulan menjadi tidak teridentifikasi.

Disarankan penggunaan pestisida secara selektif, hati-hti dan sesuai dosis yang dianjurkan, dengan menggunkan alat pelindung diri (APD) yang lebih baik, sehingga tidak berdampak pada kesehatan reproduksi wanita tani.

\section{Referensi}

Arbuckle, TE., Lin, Z \& Mery, L.S. An Exploratory Analysis of the Effect of Pesticide Exposure on the Risk of Spontaneous Abortion in an Ontario Farm Population. Environmental Health Perspectives. volume 109; 851857.2001

Abadi-Korek I, Stark B, Zaizov R, Shaham J. $J$ Occup Environ Med. 2006 Feb;48(2):165-174.

Achmadi,Umar Fahmi. Manajemen penyakit berbasis wilayah. jakarta: PT. Kompoas media nuswantoro, 2005.

Allsop M, Huxdorff C, Johnston P, Santillo D, Thompson K. Pesticide and our health a growing concern. University of Exeter Exeter EX4 4RN United Kingdom: Greenpeace Research Laboratories School of Biosciences Innovation Centre Phase 2 Rennes Drive 2015

Berhubungan dengan Fungsi Tiroid pada PUS di Kecamatan Kersana Kabupaten Brebes. Semarang: Magister Kesehatan Lingkungan, Universitas Diponegoro; 2010.

Egeghy PP. et.al. Review of Pesticide Urinary Biomarker Measurements from Selected US EPA Children's Observational Exposure Studies. J. Environ. Res. Public Health. 2011;8:1727-1754.

Food and Agriculture Organisation of The United Nations (FAO). Woman in Agricultural Development. FAO's Plan of Action. Rome, 1990 
Hoang TS, Nguyen TG. Organochlorine pesticides and Polychlorinated Biphenils in Human Breast Milk in Suburb of Hue City, Vietnam: Preliminary Result. Journal of Science Hue University. 2010

Hoang TS, Nguyen TG. Organochlorine pesticides and Polychlorinated Biphenils in Human Breast Milk in Suburb of Hue City, Vietnam: Preliminary Result. Journal of Science Hue University. 2010.

Kim, G.H., Karen, H., Raul, A.S., Nina, T.H., Asa, B., Dana, B.B., Brenda, E..Association of Organophosphate Pesticide Exposure and Paraoxonase with Birth Outcome in MexicanAmerican Women. Public Library Of Science 8(6): 1-10. 2011

Kusumawati R. Beberapa Faktor-faktor yang

Liang, W., Tiejian, W., Xuefeng, L., James, L.A., Arsham, A., Maosun, F., Jun, L.. Pesticide exposure during pregnancyand low birth weight. WHO South-East Asia Journal of Public Health 1(3):232-238. 2012

Mukono J, dkk. Penelitian Kadar Kolinesterase Petani Pemakai Pestisida di Daerah Pertanian Tanaman Pangan di Desa Punten Kabupaten Magelang dan Desa Karangan Kabupaten Trenggalek. Surabaya: Majalah Kedokteran Surabaya, 1985, Vol. XXVI nomor 3

Murphy LE, Gollenberg AL, Buck Louis GM, Kostyniak PJ, Sundaram R. Maternal serum preconception polychlorinated biphenyl concentrations and infant birth weight. Environ Health Perspect. Feb 2010;118(2):297-302
Priyanto. Toksikologi (Mekanisme, Terapi Antidotum dan Penilaian Resiko). Depok: Leskofi (Lembaga Studi dan Konsultasi Farmakologi); 2009.

$\mathrm{R}$, Wudianto. petunjuk penggunaan pestisida jakarta: swadaya, 2008

Roberts, J.R., Catherine, J. K. Pediatrics.America. Official Journal of The American Academy of Pediatrics 20126 (130). 2012

Sari, Noni, Kartika, dkk. Hubungan Riwayat pajanan Pestisida pada Ibu Hamil dengan Kejadian Berat Badan Lahir Rendah (BBLR) di Wilayah Kerja Puskesmas Wanasari Kabupaten Brebes. Jurnal Kesehatan Masyarakat Universitas Diponogoro. 2013. [Diunduh 30 Januari 2017].

Sathyanarayana, sheela et al. Maternal Pesticide Use and Birth Weight in the Agricultural Health Study. 2010

Setiyobudi, Bambang dkk. 2013. Hubungan Paparan Pestisida pada Masa Kehamilan dengan Kejadian Berat Badan Bayi Lahir Rendah (BBLR) di Kecamatan Ngablak Kabupaten Magelang

Siwiendrayanti A. Hubungan Riwayat Pajanan Pestisida dengan Kejadian Fungsi Hati (Studi Kasus Pada Wanita Usia Subur di Kecamatan Kersana Brebes). Semarang: Universitas Diponegoro; 2010

U.S. EPA. 2002. Revised OP (Organophosphate) Cumulative Risk Assessment. Washington, DC:U.S. EPA, Office of Pesticide Programs

Zhang Y, et aL. Prenatal Exposure to Organophosphate Pesticides and 
Jurnal Ilmu Keperawatan Maternitas, Volume 1 No 1, Mei 2018, hal 31-38

Neuro Behavioral Development of

Neonates: a Birth Cohort Study in

Shenyang, China. PLoS ONE.

2014;9(2):e88491,

DOI:88410.81371/journal. www.

plosone.org. 